\title{
Alloactinosynnema album gen. nov., sp. nov., a member of the family Actinosynnemataceae isolated from soil
}

\author{
Li-Jie Yuan, ${ }^{1,2} \dagger$ Yu-Oin Zhang, ${ }^{1,3} \dagger$ Li-Yan Yu, ${ }^{1}$ Hong-Yu Liu, ${ }^{1}$ Yan Guan, \\ Jae-Chan Lee, ${ }^{3}$ Chang-Jin $\mathrm{Kim}^{3}$ and Yue-Oin Zhang ${ }^{1}$ \\ ${ }^{1}$ Institute of Medicinal Biotechnology, Chinese Academy of Medical Sciences \& Peking Union \\ Medical College, Beijing 100050, PR China \\ ${ }^{2}$ Department of Biology, North China Coal Medical College, Tangshan, Hebei 063000, PR China \\ ${ }^{3}$ Biological Resource Center, Korea Institute of Bioscience and Biotechnology (KRIBB), Daejeon \\ 305-806, Republic of Korea
}

Correspondence

Yu-Qin Zhang

zhyuqin@126.com

Yue-Qin Zhang

zyq_0525@yahoo.com.cn
The family Actinosynnemataceae was proposed by Labeda \& Kroppenstedt (2000) to accommodate actinomycetes which display a type III cell-wall composition (mesodiaminopimelic acid, with galactose and rhamnose as diagnostic whole-cell sugars), type PII phospholipid pattern and MK- $9\left(\mathrm{H}_{4}\right)$ as the predominant menaquinone. The $\mathrm{G}+\mathrm{C}$ content of the genomic DNA ranged from 68 to $76 \mathrm{~mol} \%$. At the time of writing, the family encompasses six genera with validly published names, Actinokineospora (Hasegawa, 1988), Actinosynnema (Hasegawa et al., 1978), Lentzea (Labeda et al., 2001), Saccharothrix (Labeda, 1986; Labeda \& Lechevalier, 1989), Lechevalieria (Labeda et al., 2001) and Umezawaea (Labeda \& Kroppenstedt, 2007). In this paper, we report a polyphasic taxonomic study on

†These authors contributed equally to this work.

The GenBank/EMBL/DDBJ accession number for the 16S rRNA gene sequence of strain 03-9939 ${ }^{\top}$ is EU438907.

Scanning electron micrographs of growth of strain 03-9939 ${ }^{\top}$ and its cellular fatty acid profile are available as supplementary material with the online version of this paper. strain $03-9939^{\mathrm{T}}$, isolated from a soil sample collected from Xinjiang province, China.

Strain $03-9939^{\mathrm{T}}$ was isolated following incubation at $28{ }^{\circ} \mathrm{C}$ for 3 weeks on Czapek's agar (Waksman, 1961). The purified strain was maintained on ISP 2 agar slants at $4{ }^{\circ} \mathrm{C}$ and as glycerol suspensions $(20 \%, \mathrm{v} / \mathrm{v})$ at $-20{ }^{\circ} \mathrm{C}$. Biomass for molecular systematic and chemotaxonomic studies was obtained by cultivation in shake flasks using tryptic soy broth (Difco) at $28{ }^{\circ} \mathrm{C}$ for 7 days. Cultural characteristics of the isolate were determined after growth for 7-28 days at $28{ }^{\circ} \mathrm{C}$ on ISP 2, ISP 3 , ISP 4, ISP 5 (Shirling \& Gottlieb, 1966), Czapek's agar (Waksman, 1961), nutrient agar (Difco) and potato agar (Waksman, 1961). The morphology of spore chains and structures resembling sporangia was examined using gold-coated dehydrated specimens of 14-day cultures from tryptone soy agar (TSA; Oxoid), ISP 2 and ISP 4 agar with a scanning electron microscope (Quanta; FEI). The coverslip technique (Zhou et al., 1998) was employed to observe the characteristics of hyphae and spore chains.

Good growth was observed on tested media for strain 03$9939^{\mathrm{T}}$. White or buff to pink vegetative hyphae were 
abundant, well-developed and fragmented into rod-shaped elements. Wrapped structures resembling sporangia were produced on the surface of the substrate mycelium on TSA (Supplementary Fig. S1a, available in IJSEM Online). White aerial hyphae were produced on tested media. Rod-shaped, smooth-surfaced spores were formed by fragmentation of the aerial hyphae (Supplementary Fig. S1b). The spore chains and aerial mycelium always aggregated into clusters (Supplementary Fig. S1c). Buff, diffusible pigment was produced on ISP 2, ISP 3, ISP 5 and Czapek's agar. These morphological characters were consistent with the typical properties of members of the family Actinosynnemataceae (Labeda \& Kroppenstedt, 2000).

Growth was tested at $0,4,10,15,20,28-37$ (at intervals of $\left.1.0{ }^{\circ} \mathrm{C}\right), 40,45$ and $55{ }^{\circ} \mathrm{C}$ on ISP 2 . Other physiological and biochemical tests were performed at $28{ }^{\circ} \mathrm{C}$. The $\mathrm{pH}$ range was examined at $\mathrm{pH} 4.0-11.0$ (at intervals of $0.5 \mathrm{pH}$ units). Tolerance of $\mathrm{NaCl}[0,1,3$ and $5-10 \%$ (at intervals of $0.5 \%), \mathrm{w} / \mathrm{v}]$ and phenol $(0.05,0.1,0.5$ and $1.0 \%)$ was examined using ISP 2 as basal medium. Carbon source utilization was tested as described by Shirling \& Gottlieb (1966) and also by using API $50 \mathrm{CH}$ strips according to the manufacturer's instructions (bioMérieux). Enzyme activities were examined qualitatively using the API ZYM test kit (bioMérieux). Other physiological tests and antimicrobial activities were examined following procedures described previously (Yuan et al., 2008).

Good growth occurred at $28-37^{\circ} \mathrm{C}, \mathrm{pH}$ 6-8 and with $0-$ $3 \%(\mathrm{w} / \mathrm{v}) \mathrm{NaCl}$. Gelatin, starch and aesculin were hydrolysed, but not urea. Nitrate was reduced, while $\mathrm{H}_{2} \mathrm{~S}$ was not produced. Milk was coagulated and peptonized. The strain exhibited strong growth inhibition activity against Staphylococcus aureus CPCC 100051 and Pseudomonas aeruginosa CPCC 100109. The detailed physiological and biochemical characteristics of strain 03$9939^{\mathrm{T}}$ are given in the species description.

The whole-cell sugar pattern and diagnostic isomers of diaminopimelic acid were determined by TLC (Lechevalier \& Lechevalier 1965; Lechevalier \& Lechevalier 1980). Menaquinones were extracted and analysed following the method of Collins (1985). Polar lipids were extracted, examined by two-dimensional TLC and identified using published procedures (Minnikin et al. 1979). Cellular fatty acids were prepared and analysed following the standard Sherlock Microbial Identification System (MIDI, Inc.) (Sasser, 1990; Kämpfer \& Kroppenstedt, 1996).

Whole-cell hydrolysates of strain $03-9939^{\mathrm{T}}$ contained galactose and ribose. The diagnostic diamino acid was meso-diaminopimelic acid. The phospholipids comprised diphosphatidylglycerol, phosphatidylglycerol and phosphatidylcholine. The predominant menaquinone was MK$9\left(\mathrm{H}_{4}\right)(95.1 \%)$, with minor amounts of MK-9 $\left(\mathrm{H}_{6}\right)(4.9 \%)$. The detailed cellular fatty acid profile is given in Supplementary Table S1; iso- $\mathrm{C}_{16: 0}$ and iso- $\mathrm{C}_{16: 1} \mathrm{H}$ were the major fatty acids.
Extraction of genomic DNA and amplification of the $16 \mathrm{~S}$ rRNA gene were carried out as described by Li et al. (2007). Purified PCR products were sequenced with an ABI PRISM automatic sequencer. Multiple alignments with sequences of the most closely related taxa and calculations of levels of sequence similarity were carried out using CLUSTAL_X (Thompson et al., 1997). Subsequently, a phylogenetic analysis was performed using the software package MEGA 3 (Kumar et al., 2004). Distances were calculated using distance options according to Kimura's two-parameter model (Kimura, 1980, 1983) and clustering was performed with the neighbour-joining method (Saitou \& Nei, 1987). Bootstrap analysis (1000 resamplings) was used to evaluate the tree topology of the neighbour-joining data (Felsenstein, 1985). The $\mathrm{G}+\mathrm{C}$ content of genomic DNA was determined to be $68.2 \mathrm{~mol} \%$ using the thermal denaturation $\left(T_{\mathrm{m}}\right)$ method (Marmur \& Doty, 1962), with DNA of Escherichia coli AS 1.365 as a control.

A nearly complete $16 \mathrm{~S}$ rRNA gene sequence (1442 bp) of strain $03-9939^{\mathrm{T}}$ was obtained. BLAST search results using the 16S rRNA gene sequence of strain $03-9939^{\mathrm{T}}$ showed that the new isolate exhibited highest similarity to members of the family Actinosynnemataceae. In the phylogenetic tree based on the 16S rRNA gene sequences of members of all genera in the family Actinosynnemataceae (Fig. 1), strain $03-9939^{\mathrm{T}}$ formed a distinct lineage next to the genus Actinokineospora. Additionally, analysis of the 16S rRNA sequence of strain $03-9939^{\mathrm{T}}$ demonstrated that $03-9939^{\mathrm{T}}$ contained the nucleotide signatures T-A $(823: 975)$ and GC (824: 874) diagnostic for the family Actinosynnemataceae (Labeda \& Kroppenstedt, 2000); meanwhile, strain 03$9939^{\mathrm{T}}$ also possessed unique 16S rRNA signature nucleotides compared with other genera of the family Actinosynnemataceae, namely 603:635 (C-G), 617:623 $(\mathrm{U}-\mathrm{C})$ and 619 (U) (this study and Labeda \& Kroppenstedt, 2007).

The chemotaxonomic characteristics of strain $03-9939^{\mathrm{T}}$ were consistent with those of members of the family Actinosynnemataceae, e.g. meso-diaminopimelic acid as the cell-wall diamino acid, MK-9 as the principal menaquinone, straight-chain saturated and mono-unsaturated and iso- and anteiso-branched fatty acids and a relatively high DNA G + C content $(68.2 \mathrm{~mol} \%)$, within the range $68-$ $76 \mathrm{~mol} \%$. The high $16 \mathrm{~S}$ rRNA gene sequence similarities between the new isolate $03-9939^{\mathrm{T}}$ and members of the family Actinosynnemataceae also support the affiliation of strain $03-9939^{\mathrm{T}}$ with this family. However, significant differences in chemotaxonomic characteristics between strain $03-9939^{\mathrm{T}}$ and the phylogenetically most closely related genera of the family Actinosynnemataceae listed in Table 1 distinguish strain $03-9939^{\mathrm{T}}$ clearly from other genera of the family Actinosynnemataceae; galactose and ribose are present in the whole-cell sugar pattern without mannose or rhamnose, and diphosphatidylglycerol, phosphatidylglycerol and phosphatidylcholine are present as polar lipids without phosphatidylethanolamine. This distinction is supported by the position of strain 03- 


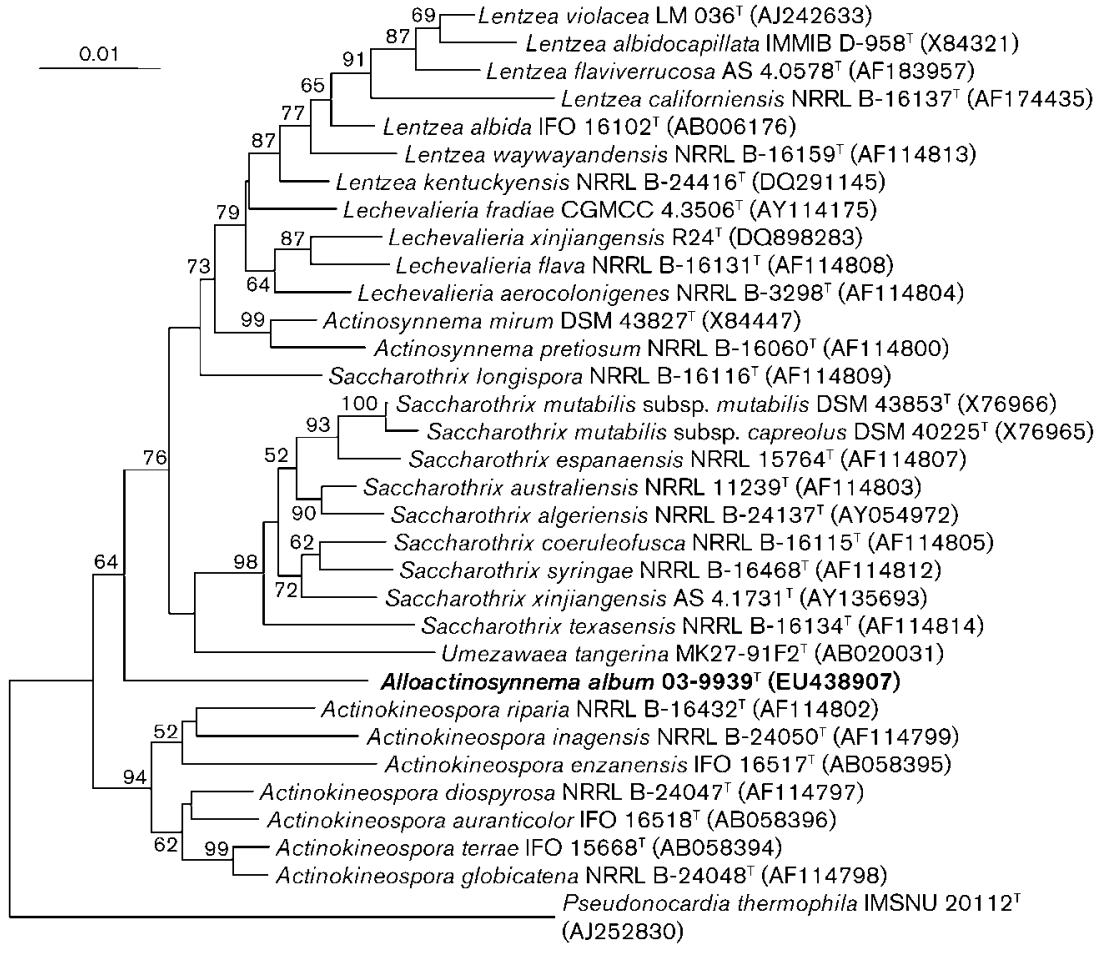

Fig. 1. Neighbour-joining tree based on $16 \mathrm{~S}$ rRNA gene sequences showing the phylogenetic relationships among strain $03-9939^{\top}$ and type strains of related genera within the family Actinosynnemataceae. Numbers at branch nodes are bootstrap values (percentages of 1000 replicates). Bar, 1 substitution per 100 nucleotide positions.
$9939^{\mathrm{T}}$ in the 16S rRNA gene sequence-based phylogenetic tree and by the diagnostic nucleotide signature pattern. Therefore, the studied strain should not be classified within any of the known genera of the family Actinosynnemataceae. On the basis of both phylogenetic and phenotypic distinctions, we propose that strain $03-9939^{\mathrm{T}}$ should be classified as representing a novel species within a new genus, for which the name Alloactinosynnema album gen. nov., sp. nov. is proposed.

\section{Description of Alloactinosynnema gen. nov.}

Alloactinosynnema (Al.lo.ac.ti.no.syn.ne'ma. Gr. adj. allos other; N.L. neut. n. Actinosynnema a bacterial generic name; N.L. neut. n. Alloactinosynnema the other Actinosynnema, referring to the fact that it is morphologically similar to Actinosynnema but chemotaxonomically and phylogenetically distinct).

Aerobic, Gram-stain-positive. Lysozyme-resistant. Extensively branched, white or buff to pink substrate mycelium may fragment into rod-shaped elements. White aerial hyphae are produced, which differentiate into long chains of smoothsurfaced spores. The spore chains and aerial mycelium often aggregate into clusters. Structures resembling sporangia are produced on some media. Diffusible buff pigments are produced on some media. Contain meso-diaminopimelic acid as the diamino acid. The whole-cell sugar pattern consists of galactose and ribose. The phospholipid pattern consists mainly of diphosphatidylglycerol, phosphatidylglycerol and phosphatidylcholine. The predominant menaquinone is MK- $9\left(\mathrm{H}_{4}\right)$. The fatty acid profile consists of straightchain saturated and mono-unsaturated and iso- and anteiso-branched fatty acids. The $\mathrm{G}+\mathrm{C}$ content of the genomic DNA of the type strain of the type species is $68.2 \mathrm{~mol} \%$. The $16 \mathrm{~S}$ rRNA gene contains a genus-specific pattern of diagnostic nucleotide signatures, namely 603:635 $(\mathrm{C}-\mathrm{G}), 617: 623(\mathrm{U}-\mathrm{C})$ and $619(\mathrm{U})$. The type species is Alloactinosynnema album.

\section{Description of Alloactinosynnema album sp. nov.}

Alloactinosynnema album (al'bum. L. neut. adj. album white).

Morphological, chemotaxonomic and general characteristics are as described for the genus. Good growth occurs on ISP 2, ISP 3, ISP 4, ISP 5, Czapek's agar, nutrient agar and potato agar. Aesculin, casein, chitin, elastin, gelatin, hypoxanthine, starch, tyrosine and xylan are degraded, but not adenine, cellulose, xanthine or urea. Milk is coagulated and peptonized. Nitrate is reduced, but $\mathrm{H}_{2} \mathrm{~S}$ is not produced. Utilizes citrate, D-ribose, glucosamine, malonate, mannose, melampyrin (dulcitol), melibiose, phenylalanine, rhamnose, sorbitol, sucrose, tartrate, trehalose, turanose and xylose as sole carbon sources for energy and growth but does not use acetate, gluconate or methyl $\alpha$-D-glucoside. Positive for acid phosphatase, alkaline phosphatase, esterase lipase C8, chymotrypsin, trypsin, $\alpha$ glucosidase, $\beta$-galactosidase and $\beta$-glucosidase (API ZYM). Grows at $0-3 \%(\mathrm{w} / \mathrm{v}) \mathrm{NaCl}, 20-37^{\circ} \mathrm{C}$ and $\mathrm{pH} 6.0-8.0$. Optimal growth at $28-32{ }^{\circ} \mathrm{C}$ and $\mathrm{pH}$ 7.0-7.5. Sensitive to $0.1 \%$ phenol. Exhibits antimicrobial activity against Staphylococcus aureus and Pseudomonas aeruginosa. Major fatty acids are iso- $\mathrm{C}_{16: 0}$ and iso- $\mathrm{C}_{16: 1} \mathrm{H}$. 


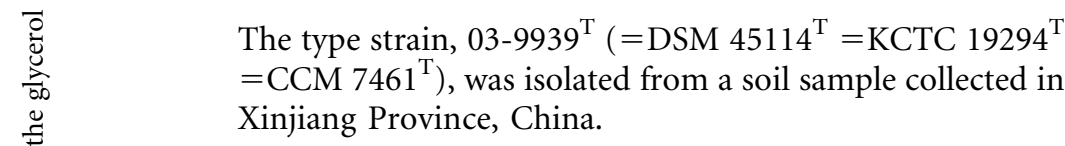

\section{Acknowledgements}

This research was supported by the National Facilities and Information Infrastructure for Science and Technology (2005DKA21203), the National Natural Science Foundation of China (NSFC) (30570040 and 30970008) and the 21C Frontier Program of Microbial Genomics and Applications from the MEST, Korea.

\section{References}

Collins, M. D. (1985). Isoprenoid quinone analysis in classification and identification. In Chemical Methods in Bacterial Systematics, pp. 267-287. Edited by M. Goodfellow \& D. E. Minnikin. London: Academic Press.

Felsenstein, J. (1985). Confidence limits on phylogenies: an approach using the bootstrap. Evolution 39, 783-791.

Hasegawa, T. (1988). Actinokineospora: a new genus of the Actinomycetales. Actinomycetologica 2, 31-45.

Hasegawa, T., Lechevalier, M. P. \& Lechevalier, H. A. (1978). A new genus of the Actinomycetales, Actinosynnema gen. nov. Int $J$ Syst Bacteriol 28, 304-310.

Kämpfer, P. \& Kroppenstedt, R. M. (1996). Numerical analysis of fatty acid patterns of coryneform bacteria and related taxa. Can J Microbiol 42, 989-1005.

Kimura, M. (1980). A simple method for estimating evolutionary rates of base substitutions through comparative studies of nucleotide sequences. J Mol Evol 16, 111-120.

Kimura, M. (1983). The Neutral Theory of Molecular Evolution. Cambridge: Cambridge University Press.

Kumar, S., Tamura, K. \& Nei, M. (2004). MEGA 3: integrated software for molecular evolutionary genetics analysis and sequence alignment. Brief Bioinform 5, 150-163.

Labeda, D. P. (1986). Transfer of "Nocardia aerocolonigenes" (Shinobu and Kawato 1960) Pridham 1970 into the genus Saccharothrix Labeda, Testa, Lechevalier, and Lechevalier 1984 as Saccharothrix aerocolonigenes sp. nov. Int J Syst Bacteriol 36, 109-110.

Labeda, D. P. \& Kroppenstedt, R. M. (2000). Phylogenetic analysis of Saccharothrix and related taxa: proposal for Actinosynnemataceae fam. nov. Int J Syst Evol Microbiol 50, 331-336.

Labeda, D. P. \& Kroppenstedt, R. M. (2007). Proposal of Umezawaea gen. nov., a new genus of the Actinosynnemataceae related to Saccharothrix, and transfer of Saccharothrix tangerinus Kinoshita et al. 2000 as Umezawaea tangerina gen. nov., comb. nov. Int J Syst Evol Microbiol 57, 2758-2761.

Labeda, D. P. \& Lechevalier, M. P. (1989). Amendment of the genus Saccharothrix Labeda et al. 1984 and description of Saccharothrix espanensis sp. nov., Saccharothrix cryophilus sp. nov., and Saccharothrix mutabilis comb. nov. Int J Syst Bacteriol 39, 419-423.

Labeda, D. P., Hatano, K., Kroppenstedt, R. M. \& Tamura, T. (2001). Revival of the genus Lentzea and proposal for Lechevalieria gen. nov. Int J Syst Evol Microbiol 51, 1045-1050.

Lechevalier, H. \& Lechevalier, M. P. (1965). Classification des actinomycetes aerobes basée sur leur morphologie et leur composition chimique. Ann Inst Pasteur (Paris) 108, 662-673 (in French).

Lechevalier, M. P. \& Lechevalier, H. A. (1980). The chemotaxonomy of actinomycetes. In Actinomycete Taxonomy (Special Publication no. 
6), pp. 227-291. Edited by A. Dietz \& D. W. Thayer. Fairfax, VA: Society for Industrial Microbiology.

Li, W. J., Xu, P., Schumann, P., Zhang, Y. Q., Pukall, R., Xu, L. H., Stackebrandt, E. \& Jiang, C. L. (2007). Georgenia ruanii sp. nov., a novel actinobacterium isolated from forest soil in Yunnan (China) and emended description of the genus Georgenia. Int J Syst Evol Microbiol 57, 1424-1428.

Marmur, J. \& Doty, P. (1962). Determination of base composition of deoxyribonucleic acid from its denaturation temperature. J Mol Biol 5, 109-118.

Minnikin, D. E., Collins, M. D. \& Goodfellow, M. (1979). Fatty acid and polar lipid composition in the classification of Cellulomonas, Oerskovia and related taxa. J Appl Bacteriol 47, 87-95.

Saitou, N. \& Nei, M. (1987). The neighbor-joining method: a new method for reconstructing phylogenetic trees. Mol Biol Evol 4, 406425.
Sasser, M. (1990). Identification of bacteria by gas chromatography of cellular fatty acids. Technical Note 101. Newark, DE: MIDI, Inc.

Shirling, E. B. \& Gottlieb, D. (1966). Methods for characterization of Streptomyces species. Int J Syst Bacteriol 16, 313-340.

Thompson, J. D., Gibson, T. J., Plewniak, F., Jeanmougin, F. \& Higgins, D. G. (1997). The CLUSTAL_X windows interface: flexible strategies for multiple sequence alignment aided by quality analysis tools. Nucleic Acids Res 25, 4876-4882.

Waksman, S. A. (1961). The Actinomycetes, vol. 2. Baltimore: Williams \& Wilkins.

Yuan, L. J., Zhang, Y. Q., Guan, Y., Wei, Y. Z., Li, Q. P., Yu, L. Y., Li, W. J. \& Zhang, Y. Q. (2008). Saccharopolyspora antimicrobica sp. nov., an actinomycete from soil. Int J Syst Evol Microbiol 58, 1180-1185.

Zhou, Z. H., Liu, Z. H., Qian, Y. D., Kim, S. B. \& Goodfellow, M. (1998). Saccharopolyspora spinosporotrichia sp. nov., a novel actinomycete from soil. Int J Syst Bacteriol 48, 53-58. 